\title{
Changing anarchism Anarchist theory and practice in a global age
}

edited by Jonathan Purkis and James Bowen

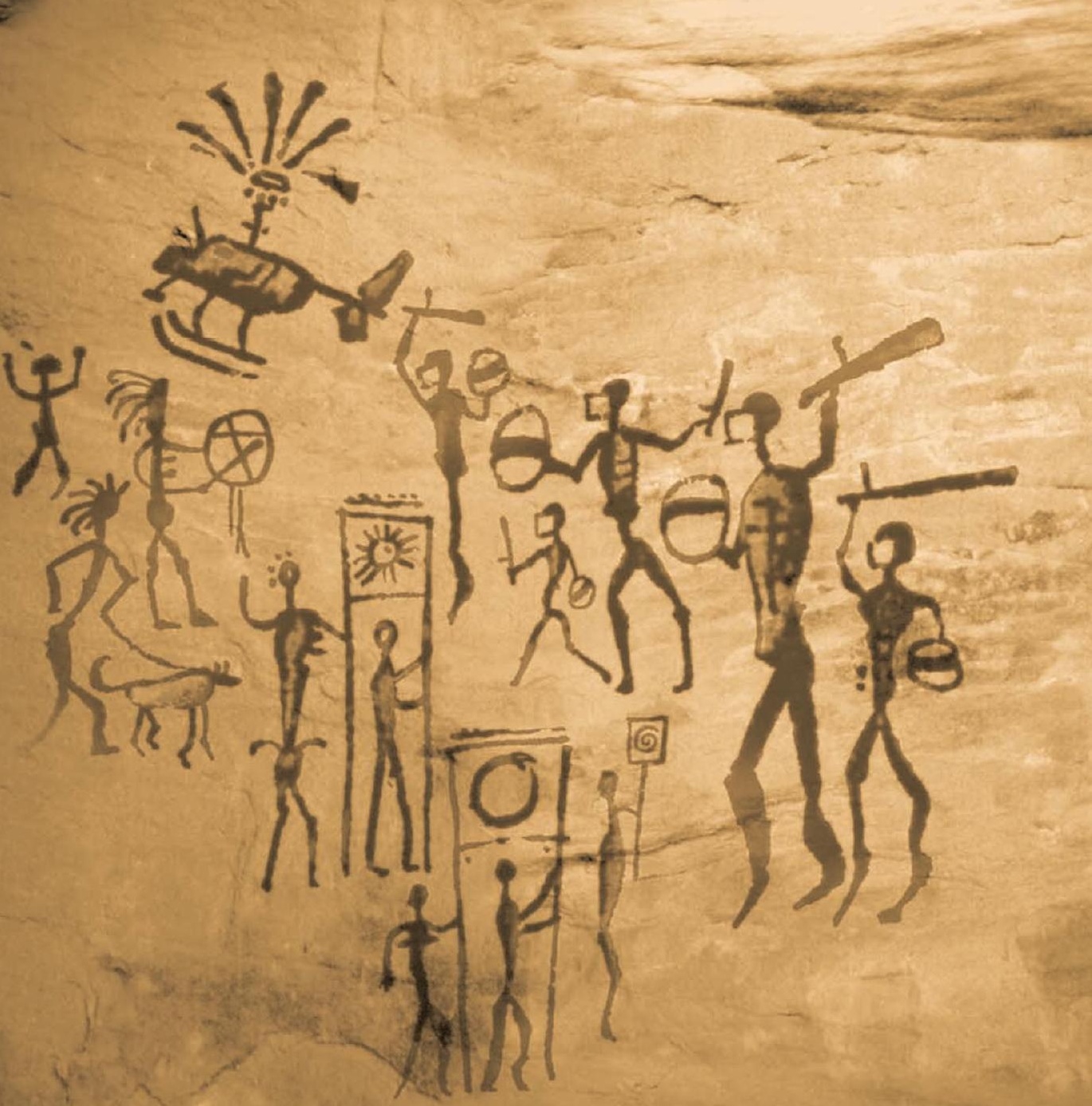




\section{Changing anarchism}

Published in our centenary year

$\approx 2004 \cong$

MANCHESTER

UNIVERSITY

PRESS 
Jonathan Purkis and James Bowen - 9781526137289 Downloaded from manchesterhive.com at 04/26/2023 08:34: ๑8AM via free access 


\section{Changing anarchism}

Anarchist theory and practice in a global age

edited by Jonathan Purkis

and James Bowen

Manchester University Press

Manchester and New York

distributed exclusively in the USA by Palgrave 
Copyright $($ Manchester University Press 2004

While copyright in the volume as a whole is vested in Manchester University Press, copyright in individual chapters belongs to their respective authors.

This electronic version has been made freely available under a Creative Commons (CC-BY-NCND) licence, which permits non-commercial use, distribution and reproduction provided the author(s) and Manchester University Press are fully cited and no modifications or adaptations are made. Details of the licence can be viewed at

https://creativecommons.org/licenses/by-nc-nd/3.0/

Published by Manchester University Press

Oxford Road, Manchester M13 9NR, UK

and Room 400, 175 Fifth Avenue, New York, NY 10010, USA

www.manchesteruniversitypress.co.uk

British Library Cataloguing-in-Publication Data

A catalogue record for this book is available from the British Library

Library of Congress Cataloging-in-Publication Data applied for

ISBN 0719066948 hardback

First published 2004

$131211 \quad 10090807060504$

10987654321

Typeset in Sabon with Gill Sans display by Servis Filmsetting Ltd, Manchester Printed in Great Britain

by CPI, Bath 